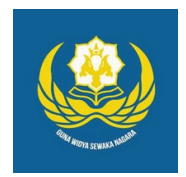

Jurnal Analogi Hukum

Journal Homepage: https://ejournal.warmadewa.ac.id/index.php/analogihukum

\title{
Penegakan Hukum Pidana Terhadap Penyelundupan Hewan Satwa
}

\author{
I Gusti Ngurah Made Suradnya*, Anak Agung Sagung Laksmi Dewi dan Luh Putu Suryani \\ Universitas Warmadewa, Denpasar-Bali, Indonesia \\ *gustingurah516@gmail.com
}

How To Cite:

Suradnya, I, G, M., Dewi, A, A, S, L., Suryani, L, P. (2021). Penegakan Hukum Pidana Terhadap Penyelundupan Hewan Satwa. Jurnal Analogi Hukum. 3 (2). 161-164. Doi: https://doi.org/10.22225/ah.3.2.2021.161-164

\begin{abstract}
Animals that must be protected where it gets protected by the government. Which in this case makes the public should not take actions that are not following the rules set by the government in this case against protected animals. If seen in article 1 number 1 law No. 5 of 1990 on Conservation of Natural Resources mentioned that individual animals are animals that grow and live on land, air, and water that have different wild properties, even those maintained by humans or live in the wild. The formulation in this study is as follows how is the legal regulation of animal smuggling and how are criminal sanctions against animal smuggling. The method used is a method of normative legal research. It is expected that the government and the people of Indonesia, in particular, to be willing to participate in protecting and eradicating people in terms of hunting protected wild animals, where it aims to keep rare animals around us sustainable
\end{abstract}

Keywords: animals; criminal policy; protection

\begin{abstract}
Abstrak - Satwa yang harus dilindungi dimana mendapat suatu perlindungan oleh pemerintah. Yang dimana dalam hal ini membuat masyarakat tidak boleh berbuat tindakan-tindakan yang tidak benar dengan aturan yang sudah ditetapkan oleh pemerintah dalam hal ini terhadap satwa dilindungi. Jika dilihat pada pasal 1 angka 1 UU No 5 Tahun 1990 tentang Konservasi Sumber Daya Alam disebutkan bahwa satwa tersendiri adalah binatang yang tumbuh dan hidup di darat, udara dan air yang memiliki sifat liar yang berbeda-beda, bahkan yang dipelihara oleh manusia ataupun hidup di alam bebas. Rumusan dalam penelitian ini sebagai berikut bagaimanakah pengaturan hukum penyelundupan hewan satwa dan bagaimanakah sanksi pidana terhadap penyelundupan hewan satwa. Adapun metode yang digunakan adalah metode penelitian hukum normatif. Diharapkan pemerintah dan masyarakat Indonesia khususnya untuk mau ikut melindungi serta memberantas orang-orang dalam hal perburuan hewan liar yang dilindungi, dimana hal tersebut bertujuan agar hewan langka yang ada disekitar kita tetap lestari.
\end{abstract}

Kata Kunci: satwa; kebijakan pidana; perlindungan.

\section{Pendahuluan}

Sudah seharusnya satwa diberikan perlindungan karena jika kita lihat populasinya yang sedikit akan membuat ancaman karena minimnya ilmu pengetahuan yang dimiliki oleh masyarakat besar mengenai nilai-nilai penting, mengakibatkan semakin besar ancaman yang membuat kepunahan, seperti pemeliharaan dan perdagangan, perburuan liar dan perusakan terhadap habitat satwa.

Satwa yang harus dilindungin dimana mendapat suatu perlindungan oleh pemerintah. Yang dimanat masyarakat tidak boleh melakukan perbuatan yang tidak sesuai dengan aturan yang sudah ditetapkan oleh pemerintah dalam hal ini terhadap hewan langka.

Pada dasarnya negara kita dimana dikenal sebagai negara kepulauan yang sangat kaya akan hewan langka yang menjadi satwa endemik indonesia yang memiliki bentuk yang sangat beda di setiap wilayahnya yang tidak akan bisa ditemukan di wilayah lainnya. (Koesnandi Hardjasoemantri, 2009 64) 
Jika dilihat tentang Konservasi Sumber Daya Alam menyebutkan bahwa satwa tersendiri adalah binatang yang tumbuh dan hidup di darat, udara dan air yang memiliki sifat liar yang berbeda-beda, bahkan yang dipelihara oleh manusia ataupun hidup di alam bebas. Pada dasarnya satwa liar adalah satwa yang tidak boleh untuk di buru, dimiliki, dipelihara dan atau diperjualbelikan, namun jika kita lihat masyarakat indonesia belum paham mana hewan satwa yang dilindungi atau tidak. (Leden Marpaung, 1995 47)

Sanksi pidana kumulatif adalah dasar penerapan sanksi yang diberi kepada orang yang melakukan penyelundupan, karena tindakan penyelundupan adalah bentuk tindak pidana atau kejahatan yang memberikan kerugian terhadap negara, merusak sendi perekonomian dan stabilitas perekonomian, dan juga memberi kerugian kepada potensi negara yang diharapkan bisa untuk membiayai segala pembangunan yang ada dalam hal membuat masyarakat indonesia sejahtera.

Karena hal tersebut, pelaku yang melakukan suatu penyelundupan harus dikenakan sanksi pidana yang sifatnya alternatif dimana dengan tujuan agar UU Kepabeanan ditaati dan dilakukan untuk memberi peningkatan devisa dan pendapatan negara indonesia. Dimana sanksi pidana yang tidak dilakukan secara kumulatif bisa mengakibatkan tidak diutamakannya penerima keuangan, karena sifat kumulatif sebagai sanksi pidana tidak hanya untuk memberi penegakan kewibawaan terhadap pemerintah. Dari yang telah diuraikan tersebut, maka penulis tertarik untuk melakukan penelitian dan mengkaji tentang penegakan hukum pidana terhadap penyelundupan hewan satwa. Hasil paparan masalah yang dijelaskan timbullah pertanyaan untuk permasalahan tersebut, yakni; Bagaimanakah pengaturan hukum penyelundupan hewan satwa?; Bagaimanakah sanksi pidana terhadap penyelundupan hewan satwa?

\section{Metode}

Penelitian skripsi ini memakai penelitian hukum secara normatif, dimana mengacu kepada studi kepustakaan di bidang hukum, dengan menggunakan pendekatan masalah secara konseptual dan pendekatan kasus.

Dengan menggunakan yaitu bahan hukum primer berpedoman terhadap undang-undang dan keputusan terikat. Bahan diperoleh dimana didapat melalui jurnal, buku hukum, serta internet yang memuat mengenai penghinaan dimedia sosial terhadap seorang individu yang sudah meninggal dunia.

Didapatkan melalui kamus hukum serta ensiklopedia yang berkaitan mengenai informasi hukum. Hal ini dilakukan dengan cara mencatat, mengutip, membaca, maupun meringkas literatur yang mengacu terhadap perubahan status jenis kelamin di indonesia. Menganalisis setiap bahan buku yang dipergunakan untuk memilih yang sesuai dengan topik dari penelitian skripsi yang mana akan di analisis dengan sistematis dan mengaitkannya dengan bahan hukum.

\section{Hasil Penelitian Dan Pembahasan}

\section{Pengaturan Hukum Tentang Penyelundupan Hewan Satwa}

Hukum pidana adalah aturan keseluruhan mengenai suatu perbuatan yang ada aturan dan hukumannya. Menurut Moeljatmo berpendapat bahwa, hukum pidana sebuah keseluruhan hukum yang ada di negara yang memuat suatu dasar dan aturan untuk menentukan perbuatan yang dilarang, yang tidak boleh dilakukan, dan berisi sanksi dan pidana bagi siapapun yang melanggar aturan tersebut, menentukan hal- hal kepada tersangka yang melanggar bisa dijatuhkan ataupun dikenakan pidana sebagaimana yang telah dibuat, menentukan bagaimana pengenaan suatu perbuatan pidana bisa dilakukan jika orang yang telah disangka telah melanggarnya. (Moeljatno, 2008 1)

Menurut Kartanegara dipandang dari beberapa sudut mengenai hukum pidana yaitu Hukum Pidana secara Objektif, dimana terdapat pearutan yang memuat larangan kepada orang yang telah melanggar dan dapat diberi ancaman hukum dan Hukum Pidana secara Subjektif, dimana terdapat peraturan yang memberi aturan untuk memberi huykum kepada seseorang atas perbuatan yang telah dilarang. (Teguh Prasetya, 2011 7) Tri Andrisman mengatakan tentang pidana dimana adalah suatu nestapa yang diberi sengaja dan diberikan beban terhadap seseorang yang telah melakukan suatu perbuatanperbuatan yang telah memenuhi sebuah syarat. Dalam hukum pidana, pidana mutlak sangat diperlukan yang mana tujuannya agar bisa menjadi suatu sarana pencegahan khusus maupun umum bagi seluruh masyarakat agar tidak melanggarnya. (Tri Andrisman, 2009 8). Dimana jika dilihat hukum pidana materiil sendiri merupakan seluruh hukum dan peraturan yang memuat aturan terhadap perbuatan badan atau seseorang yang dilakukan melanggar suatu hukum pidana yang mana bisa diberikan ancaman berupa sanksi pidana. Berbeda dengan 
hukum pidana formal merupakan seluruh norma hukum dan peraturan yang memberi sebuah aturan-aturan cara mempertahankan dan melaksanakan hukum pidana materiil. Dimana hukum pidana formal sendiri merupakan segala peraturan hukum yang memberi aturan mengenai tindakan hukum yang mana apabila terduga terjadinya suatu tindakan pidana. (Umar Said Sugiarto, 2015 234). Suatu aturan yang mengenai tindak pidana satwa terdapat dalam UU Nomor 5 Tahun 1990 pada pasal 40 ayat 2, barang siapa yang melanggar Pasal 21 ayat 2 berbunyi, setiap orang dilarang

Menangkap, membunuh, melukai, memiliki memelihara, menyimpan, dan memperniagakan hewan dalam kondisi hidup, Menyimpan, mengangkut, memiliki, memelihara dan memperniagakan hewan dalam kondisi tidak hidup, Membebaskan satwa dari negara indonesia ke tempat lain di luar negara indonesia sendiri, Memperagakan, menyimpan dan memiliki tubuh, kulit atau bagian yang terdapat pada satwa yang dilindungi, Mengambil, memusnahkan, merusak, memiliki atau menyimpan sarang atau telur satwa dilindungi.

Tindakan pidana kepada hewan dilindungi pada masa-masa yang datang dimana belum dilakukan suatu konsep RUU KUHP tahun 2012 saat ini belum mendapatkan pengesahan. Tindak pidana penganiayaan ringan terhadap satwa yang tercantum pada pasal 501 RUU KUHP Dengan sengaja melukai dan menyakiti satwa atau memberi kerugian kesehatan terhadap satwa tersebut, Dengan sengaja dengan alasan tidak pasti dan melampaui batas-batas yang sudah ditentukan untuk menggapai maksud tersebut, tidak memberi kebutuhan tidak memberi makanan kepada satwa yang sebagian atau seluruhnya hak milik di bawah suatu pengawasan, atau terhadap satwa yang bisa dipelihara, Dengan sengaja berbuat dan atau bersetubuh terhadap satwa.

Tanggung jawab pidana atas kesalahan dimana Sudarto menjelaskan dimana kealpaan dan kesengajaan. Kesengajaan yang dimaksud disini adalah berdasar suatu tingkatnya yaitu, kesengajaan tersebut bermaksud, kesengajaan dengan kondisi sadar dan kesengajaan dengan kondisi sadar dengan suatu kepastian. Tanggung jawab pidana kepada tindakan pengaiayaan ringan terhadap stawa terdapat pada RUU KUHP yang terdapat didalam Pasal 501 seseorang yang belum memiliki suatu kebenaran dan atau keterangan terhadap korporasi. Satawa yang mendapat suatu perlindungan menurut peraturan perundang- undangan terdapat suatu pengklasifikasi dan sebutan secara yuridis yang diamaksud pelanggaran dan suatu kejahatan. Dalam suatu bab yang telah ditentukan dalam pidana harus terdapat suatu penegasan dan atau ketentuan mengenai suatu kualifikasi dari suatu perbuatan tindak pidana yang mana sebagai tindakan kejahatan dan atau perbuatan pelanggaran, karena adanya aturanaturan yang terdapat di KUHP yang mana terdapat aturan umum untuk suatu adanya pelanggaran dan aturan umum yang menyangkut tentang kejahatan.

Penempatan terhadap suatu delik pelanggaran dan atau kejahatan dimana dasarnya adalah suatu ketetapan kualifikasi yuridis yang memiliki suatu akibat dimana akibat tersebut bisa berupa yuridis pula maupun yuridis materil dimana kaitannya dengan suatu aturan-aturan yang berkaitan dengan KUHP ataupun suatu konsekuensi formal yang ada dalam KUHAP, semasih tidak ada penentuan oleh suatu undangundang. Suatu penetapan terhadap kualifikasi diperlukan adanya suatu jembatan yang di dalamnya berlaku aturan-aturan umum KUHP kepada suatu hal yang tidak ada di dalamnya.

\section{Sanksi Pidana Terhadap Penyelundupan He- wan Satwa}

Sanksi adalah suatu bahasa yang dimana didapat dari sebuah bahasa Belanda sanctie yang didalamnya poenale yang banyak dikenal pada masa-masa sejarah yang ada di Indonesia. Dengan arti lain dimana didalamnya berisikan konteks suatu hukum, sanksi mempunyai sebuah arti dalam hukum yang mana hanya dapat dijatuhkan dari pihak pengadilan dan terdapat di dalamnya sebuah konteks yang berkaitan sosiologi, yang dimana artinya kontrol sosial adalah sanksi.

Sanksi hukum adalah hukuman yang hanya bisa terjadi dan diberikan terhadap seseorang yang berbuat suatu pelanggaran terhadap hukum. Dimana ini suatu bentuk yang wujudnya jelas dari negara di dalam menjalankan halhal yang wajib didalam seharusnya mentaati suatu aturan-aturan yang sudah ada. Dalam suatu pelanggaran peraturan dimana sudah umum yang harus campur tangan terhadap adanya pelanggaran-pelanggaran adalah pihak pemerintah. Dengan adanya alat yang bisa memaksakan pemerintah sendiri akan lebih mudah memaksa seseorang untuk mau mengikuti segala kaidah tata tertib yang dibuat oleh pemerintah untuk masyarakatnya sendiri. Macam sanksi di Indonesia Sanksi pidana, Sanksi perdata dan Sanksi administrasi. Sudah semestinya seluruh masyarakat dilarang menangkap satwa yang sudah terdaftar hewan yang sudah dilindungi, siapapun yang berani 
melakukannya itu adalah hal yang termasuk dalam tindak pidana. Jika dilihat pada pasal 1 angka 5 UU nomor 5/1990 menjabarkan suatu definisi terhadap hewan, dimana semua jenis sumber daya hewani yang hidup di air/darat dan diudara.

Sedangkan dalam pasal 20 ayat $1 \mathrm{UU}$ 5/1990 memberikan penggolongan jenis hewan, yang dimana berbunyi Satwa dan tumbuhan digolongkan dari beberapa jenis, Satwa dan tumbuhan yang dilindungi dan Satwa dan tumbuhan yang tidak dilindungi. Lebih dalam disebutkan bahwa hewan yang mendapatkan perlindungan atau dilindungi adalah sebagai yang terlampir dalam peraturan yang sudah ditetapkan, yakni Penyu, orang utan, badak jawa, burung jalak bali, harimau sumatera, badak bercula satu, dugong, burung cendrawasih, elang flores dan lain sebagainya.

Pada umumnya, larangan yang tidak boleh dilakukan karena tidak wajar adalah terdapat di dalam pasal 21 ayat 2 UU Nomor 5/1990 yeng menyebutkan setiap orang dilarang untuk Menangkap, mengangkut, melukai, memelihara, membunuh, memiliki, menyimpan hewan saat dalam keadaan masih hidup, Menyimpan, memperagakan, memiliki, mengangkut, memelihara satwa saat dalam keadaan mati, Mengeluarkan hewan dari suatu tempat ke tempat yang lainnya bisa di dalam maupun di luar negara Indonesia, Memperagakan, memiliki kulit atau bagian dari satwa yang dilindungi ataupun benda-benda yang terbuat dari bagian satwa-satwa tersebut dan Mengambil, memusnahkan, merusak, menyimpan, memperniagakan atau memiliki sarang-sarang satwa ataupun telur-telurnya.

Sanksi yang didapatkan oleh seseorang yang dengan sengaja berbuat pelanggaran kepada ketentuan-ketentuan yang sudah dimaksud pada pasal 21 ayat 2 dimana pidana penjara paling lama 5 tahun dan mendapatkan denda Rp 100.000.000,00 (seratus juta rupiah) Adapun pengecualian terhadap satwa yang ditangkap , dengan maksud untuk ilmu pengetahuan, keperluan suatu penelitian, dan untuk menyelamatkan satwa dan tumbuhan yang terkait. Selain hal tersebut terdapat juga suatu pengecualian karena ada beberapa satwa yang dilindungi berbahaya bagi kehidupan manusia.

Bahaya yang dimaksud adalah bahaya tidak hanaya memberi ancaman jiwa manusia tetapi juga membuat keresahan dan gangguan terhadap kehidupan manusia, atau menimbulkan suatu kerugian terhadap tanaman atau lahan hasil perkebunan dan atau pertanian milik manusia. Dari apa yang sudah ditentukan diatas, kita dapat paham dan mengerti bahwa jika me- nangkap atau membunuh satwa yang dilindungi merupakan suatu kejahatan, bisa dikatakan suatu tindak pidana yang ada pada bidang konservasi.

Selain itu pula meskipun adanya penangkapan satwa yang dilindungi tersebut adalah hal atau kegiatan turun-temurun, tetap perbuatan tersebut disebut suatu kejahatan. Yang mana hal ini sudah dijelaskan pada pasal yang ada bahwa berlaku untuk setiap orang. Kasus-kasus penangkapan hewan bisa dilihat pada putusan pengadilan Nomor 304/Pid.B/2011/PN.Kpj. dimana didalamnya dijelaskan terdakwa yang masuk ke dalam taman nasional kemudian terdakwa mengeder jaring dengan membuat jaring tersebut dimana terdakwa terbentang dan tarik. Setelah dibentangkannya tali makan jika ada burung-burung yang terjerat makan akan dimasukan kedalam kantong kertas.

\section{Simpulan}

Hasil pemaparan diatas saya simpulkan sebagai berikut; Dimana penyelundupan kepada hewan yang dilindungi tidak dibuat secara pasti.dimana tindak pidana menyangkut hal perdagangan hewan liar masih dilindungi dapat mengacu pada pasal 21 ayat 2 UU Konservasi Hayati dimana terdapat ketentuan sanksi pidananya penjara paling lama 5 tahun dan dengan diberi denda $\mathrm{Rp}$ 100.000.000,00 (seratus juta rupiah). Dimana pelaku penyelendupan dapat dikenakan pasal 40 ayat 2 dan ayat 4 . Dimana perbuatan tersebut dapat dibagi menjadi pelanggaran dan kejahatan sesuai dengan ketentuan yang ada pada pasal 40 ayat 5 .

\section{Daftar Pustaka}

Hardjasoemantri, K. (2009). Hukum Perlindungan Konservasi Sumber Daya Alam dan Ekosistemnya, Yogyakarta, Edisi pertama. Yogyakarta: Gajah mada University Press.

Marpaung, L. (1995). Tindak Pidana Terhadap Hutan Hasil Hutan dan Satwa. Jakarta: PT Gelora Aksara Prata.

Moeljatno. (2008). Asas-Asas Hukum Pidana. Jakarta: Bina Aksara.

Prasetya, P. (2011). Hukum Pidana. Yogyakarta: Raja Grafindo Persada.

Andrisman, T. (2009) Asas-asas dan Aturan umum Hukum Pidana Indonesia, Bandar Lampung: Universitas Bandar Lampung.

Sugiarto, U, S. (2015). Pengantar Hukum Indonesia,. Jakarta: Sinar Grafika. 